\title{
Cytotoxic activity of Thai medicinal plants against human cholangiocarcinoma, laryngeal and hepatocarcinoma cells in vitro
}

\author{
Wiratchanee Mahavorasirikul ${ }^{1}$, Vithoon Viyanant ${ }^{1}$, Wanna Chaijaroenkul ${ }^{1}$, Arunporn Itharat ${ }^{2}$, Kesara Na-Bangchang $^{1 *}$
}

\begin{abstract}
Background: Cholangiocarcinoma is a serious public health in Thailand with increasing incidence and mortality rates. The present study aimed to investigate cytotoxic activities of crude ethanol extracts of a total of 28 plants and 5 recipes used in Thai folklore medicine against human cholangiocarcinoma (CL-6), human laryngeal (Hep-2), and human hepatocarcinoma (HepG2) cell lines in vitro.

Methods: Cytotoxic activity of the plant extracts against the cancerous cell lines compared with normal cell line (renal epithelial cell: HRE) were assessed using MTT assay. 5-fluorouracil was used as a positive control. The $\mathrm{IC}_{50}$ (concentration that inhibits cell growth by 50\%) and the selectivity index (SI) were calculated.

Results: The extracts from seven plant species (Atractylodes lancea, Kaempferia galangal, Zingiber officinal, Piper chaba, Mesua ferrea, Ligusticum sinense, Mimusops elengi) and one folklore recipe (Pra-Sa-Prao-Yhai) exhibited promising activity against the cholangiocarcinoma CL-6 cell line with survival of less than $50 \%$ at the concentration of $50 \mu \mathrm{g} / \mathrm{ml}$. Among these, the extracts from the five plants and one recipe (Atractylodes lancea, Kaempferia galangal, Zingiber officinal, Piper chaba, Mesua ferrea, and Pra-Sa-Prao-Yhai recipe) showed potent cytotoxic activity with mean $\mathrm{IC}_{50}$ values of $24.09,37.36,34.26,40.74,48.23$ and $44.12 \mu \mathrm{g} / \mathrm{ml}$, respectively. All possessed high activity against Hep-2 cell with mean $I_{50}$ ranging from 18.93 to $32.40 \mu \mathrm{g} / \mathrm{ml}$. In contrast, activity against the hepatoma cell HepG2 varied markedly; mean $I_{50}$ ranged from 9.67 to $115.47 \mu \mathrm{g} / \mathrm{ml}$. The only promising extract was from Zingiber officinal $\left(I C_{50}=9.67 \mu \mathrm{g} / \mathrm{ml}\right)$. The sensitivity of all the four cells to 5 -FU also varied according to cell types, particularly with $\mathrm{CL}-6$ cell $\left(\mathrm{IC}_{50}=757\right.$ micromolar). The extract from Atractylodes lancea appears to be both the most potent and most selective against cholangiocarcinoma $\left(I_{50}=24.09 \mu \mathrm{g} / \mathrm{ml}, \mathrm{SI}=8.6\right)$.

Conclusions: The ethanolic extracts from five plants and one folklore recipe showed potent cytotoxic activity against CL-6 cell. Sensitivity to other cancerous cell lines varied according to cell types and the hepatocarcinoma cell line. HepG2 appears to be the most resistant to the tested extracts.
\end{abstract}

\section{Background}

Cholangiocarcinoma, malignant epithelial cells that arises within bile duct, is a serious public health in Thailand with increasing incidence and mortality. The cancer occurs at a particularly high rate in Northeastern Thailand, with age-standardized incidence rate (ASRs) 33.4 per 100,000 in males and 12.3 per 100,000 in females [1]. It accounts for approximately $15 \%$ of liver cancer worldwide [2]. This cancer can be classified into three

\footnotetext{
* Correspondence: kesaratmu@yahoo.com

${ }^{1}$ Graduate Program in Biomedical Sciences, Thammasat University (Rangsit

Campus), Pathumtani 12121, Thailand

Full list of author information is available at the end of the article
}

major groups, i.e., intrahepatic, perihilar and distal extrahepatic cholangiocarcinoma. Intrahepatic type is the most common case of cholangiocarcinoma in Thailand and infestation of Opisthorchis viverrini has been classified as a definite risk factor of the disease [3]. The lack of early detection and limited therapeutic options are major problems for controlling this type of cancer. At present, surgical resection of detectable tumors leads to an improvement in the 5-year survival rate. Adjunctive therapy with chemotherapeutic agents has been shown to improve local control, provide palliation, and prolong survival [4]. Even those with operable tumor, the recurrence rate is extremely high, with a 5 -year

\section{() Biomed Central}


survival rate of less than $40 \%[5,6]$. Chemotherapeutic treatment of cholangiocarcinoma is largely ineffective; the standard chemotherapeutic agent, 5-fluorouracil (5FU) always produces low clinical response rate [6-8]. Advanced surgical techniques in conjunction with alternative chemotherapeutic option with promising activity are required to improve the survival of patients. Cholangiocarcinoma is considered to be a multidrug and radio-resistant tumor and still require new approach of treatments [9].

Numerous cancer research for chemotherapeutic potential of medicinal plants have been carried out in an effort to discover new therapeutic agents that lack the toxic effects associated with current therapeutic agents. Traditional medicine is commonly used as an alternative treatment for cancer by Thai people [10]. Several Thai traditional folklores have been shown to possess anticancer activities in various human cancerous cell lines with some promising candidates $[11,12]$. In the present study, the ethanolic extracts of a total of 28 plants and 5 recipes used in Thai folklore medicine were investigated for their cytotoxic activity in vitro against three human cancerous cell lines, i.e., CL-6 (cholangiocarcinoma), Hep-2 (laryngeal carcinoma), HepG2 (hepatocarcinoma), and HRE (renal epithelial cells). To our knowledge, this is the first study that focused on the investigation of cytotoxic activity of Thai folklore against cholangiocarcinoma.

\section{Methods}

Reagents

Commercial grade ethanol was purchased from Labscan Co. Ltd. The cell culture medium and reagents were purchased from different sources: Ham-12, RPMI 1640, M-199 medium, from Gibco BRL Life Technologies (Grand Island, NY, USA), renal epithelium cell growth medium and SupplementPack from Promacell Co. Ltd. (Germany). Fetal bovine serum (FBS), L-glutamine dimethylsulfoxide (DMSO), the antibiotic solution, streptomycin-penicillin and antibiotic-antimycotic, were purchased from Gibco BRL Life Technologies. The reference compound, 5-fluorouracil (5-FU) and MTT [3-(4,5-dimethylthiazol-2-yl)-2,5-diphenyltetrazolium bromide] were purchased from Sigma-Aldrich Inc. (St. Louis, MO, USA).

\section{Plant materials and preparation of crude extracts}

Plant materials were collected from various parts of Thailand and some were purchased from the city markets. Authentication of plant materials was carried out at the herbarium of the Department of Forestry, Bangkok, Thailand, where the herbarium vouchers have been kept. A duplicate set has been deposited in the herbarium of Southern Center of Thai Medicinal Plants at the Faculty of Pharmaceutical Science, Prince of Songkhla University, Songkhla, Thailand.

The plant materials were rinsed thoroughly with tap water to remove extraneous contaminants and cut into small pieces, oven-dried at $50^{\circ} \mathrm{C}$ until stability of dry weight was observed, and then ground into powder with an electric-grinder. Extraction was carried out by macerating the powdered plant materials (100 g) in stoppered flasks containing $500 \mathrm{ml}$ of $95 \%$ ethanol at room temperature $\left(25-30^{\circ} \mathrm{C}\right)$ for 7 days. The extracted solvent was separated and filtered through Whatman no. 1 filter paper. After filtration, the extracts were evaporated under reduced pressure by rotary evaporation. The crude extracts were weighed and stored at $-20^{\circ} \mathrm{C}$ until used.

\section{Preparation of test materials and reference drug}

The crude extract from each medicinal plant/recipe was initially dissolved in 50\% ethanol. Concentrated stock solution of each extract was prepared by adding a known weight of each crude extract to a known volume of $50 \%$ ethanol, and then serially diluted (1:2) with complete media to obtain the working solutions at eight final concentrations. Positive control agent 5-FU was prepared similarly as the crude extract by dissolving in $50 \%$ ethanol.

\section{In vitro assay for cytotoxic activity Human cell lines and cell culture}

The cholangiocarcinoma cell line CL-6, human laryngeal carcinoma cell line Hep-2, human hepatocarcinoma cell line HepG2 and normal human epithelial cell (HRE) were used for cytotoxic screening of the medicinal plant extracts. CL-6 cell line was established and kindly provided by Associate Professor Dr. Adisak Wongkajornsilp, Department of Pharmacology, Faculty of Medicine (Siriraj Hospital), Mahidol University, and were cultured in Ham-12 medium supplemented with $10 \%$ heated fetal bovine serum and $100 \mathrm{IU} / \mathrm{ml}$ of antibiotic-antimycotic solution. Hep-2 cell line was obtained from Department of Medical Technology, Faculty of Allied Health Sciences, Thammasat University, established and cultured in M-199 medium supplemented with $10 \%$ heated fetal bovine serum, $2.5 \mathrm{mM}$ HEPES ( $\mathrm{pH} 7.4)$ and $100 \mathrm{IU} / \mathrm{ml}$ penicillin-streptomycin solution. HepG2 cell line was purchased from the Cell Line Service Co. Ltd. (Germany) and was cultured in DMEM: Ham's F12 medium supplemented with $2 \mathrm{mM}$ L-glutamine, $10 \%$ fetal bovine serum and $100 \mathrm{IU} / \mathrm{ml}$ pen-strep. Normal human renal epithelial cell line (HRE) was purchased from Promocell Co. Ltd. (Germany) and cultured in renal epithelial cell growth medium 2 with SupplementPack. All cells were 
maintained at $37^{\circ} \mathrm{C}$ in a $5 \% \mathrm{CO}_{2}$ atmosphere with $95 \%$ humidity.

\section{Cytotoxic assay}

The MTT colorimetric assay developed by Mosmann [13] with modification was used to screen for cytotoxic activity of all the plant extracts. Briefly, the cells were seeded in 96-well plates at a density of $10^{4}$ cells/well in $100 \mu \mathrm{l}$ culture medium. Following 24-h incubation and attachment, the cells were treated with different concentrations of plant extracts and 5-FU (positive control) for $24 \mathrm{~h}$. Each extract was screened initially for its cytotoxicity against all cancerous and normal cell lines at the concentration of $50 \mu \mathrm{g} / \mathrm{ml}$. The potential candidates which resulted in cell survival of less than $50 \%$ were further assessed for their $\mathrm{IC}_{50}$ (concentration that inhibits cell growth by $50 \%$ ) values at the concentration range of 250 and $1.95 \mu \mathrm{g} / \mathrm{ml}$. The concentration range used for 5 -FU was 78.13 to $10,000 \mu \mathrm{M}$. Following washing and incubation with MTT solution $(20 \mu \mathrm{l}$ of $5 \mathrm{mg} /$ $\mathrm{ml}$ ) at $37^{\circ} \mathrm{C}$ for $3 \mathrm{~h}$, cells were lyzed with DMSO. The yellow MTT dye was reduced by succinic dehydrogenase in the mitochondria of viable cells to purple formazan crystals. Absorbance (OD) was measured at $570 \mathrm{~nm}$ using a microplate reader (Varioscan Flash, Thermo, Finland). The percentage of cytotoxicity compared to the untreated cells was determined with the equation:

$$
\text { Cell viability }(\%)=\frac{\text { OD of treated cells }}{\text { OD of control cells }} \times 100
$$

The results were generated from three independent experiments; each experiment was performed in triplicate. The $\mathrm{IC}_{50}$ values were calculated using CalcySyn ${ }^{\mathrm{Tm}}$ (USA) software. The selectivity index (SI) was also calculated from the $\mathrm{IC}_{50}$ ratio of normal epithelial and cancerous (CL-6, Hep-2, HepG2) cells. SI value indicates selectivity of the sample to the cell lines tested. Samples with SI value greater than 3 were considered to have high selectivity.

\section{Results and Discussion}

Plants are promising source of anti-infective and anticancer chemotherapeutic agents. Saetung and colleague selected twelve Thai medicinal plants as the ingredients of a Southern Thai traditional folklore medicine for cancer treatment to test for their cytotoxicity activity against human lung and prostate cancer cell lines. The ethanolic extracts of the six plants (Bridelia ovata, Curcuma zedoaria, Derris scandens, Dioscorea membranacea, Nardostachys jatamansi and Rhinacanthus nasutus) showed promising cytotoxic activity $\left(\mathrm{IC}_{50}<30 \mu \mathrm{g} / \mathrm{ml}\right)$ [14]. In the present study, the cytotoxic effect of a total of 28 ethanolic extracts of plants and 5 recipes from traditional folklore medicine against the human cholangiocarcinoma cell line CL-6 were investigated. In addition, their comparative activity against the other two human cancerous cell lines, i.e., Hep-2 (laryngeal carcinoma) and HepG2 (hepatocarcinoma), and one normal cell HRE (human renal epithelial cell) was also examined. These plants have been used by Thai people to treat different illness. The five recipes were used for restorativeness, treatment of fever, cold and cancer (Table 1). The eighteen plants tested were composition of Pra-Sa-Prao-Yhai recipe, and some plants were composition of other recipes (Table 1). The leave, stem, bark and rhizome parts of plants were most often used for these traditional medicines (Table 1). Results from the initial screening showed that the extracts from seven plant species (Atractylodes lancea, Kaempferia galangal, Zingiber officinal, Piper chaba, Mesua ferrea, Ligusticum sinense, Mimusops elengi) and one folklore recipe (Pra-Sa-Prao-Yhai) exhibited promising activity against the cholangiocarcinoma CL- 6 cell line with cell survival of less than $50 \%$ at the concentration of $50 \mu \mathrm{g} / \mathrm{ml}$ (Table 2). Among these, six (Atractylodes lancea, Kaempferia galangal, Zingiber officinal, Piper chaba, Mesua ferrea, and Pra-Sa-Prao-Yhai recipe) showed potent cytotoxic activity with $\mathrm{IC}_{50}$ values of less than 50 $\mu \mathrm{g} / \mathrm{ml}$. The potency of the extracts in descending order was as follow: Atractylodes lancea, Zingiber officinal, Kaempferia galangal, Piper chaba, Pra-Sa-Prao-Yhai recipe and Mesua ferrea (Table 3). The plants Atractylodes lancea, Kaempferia galangal and Mesua ferrea are also composition of Pra-Sa-Prao-Yhai recipe. In the US National Cancer Institute Plant Screening Program, a crude extract is generally considered to have in vitro cytotoxic activity if the $\mathrm{IC}_{50}$ value in carcinoma cells, following incubation between 48 and 72 hours, is less than $20 \mu \mathrm{g} / \mathrm{ml}$, while it is less than $4 \mu \mathrm{g} / \mathrm{ml}$ for pure compounds [15]. Based on this criteria, only the extract from Atractylodes lancea is considered highly active with $\mathrm{IC}_{50}$ of $24.04 \pm 3.40$ (mean \pm SD) $\mu \mathrm{g} / \mathrm{ml}$. The extract from Dioscorea membranacea showed only weak activity in the screening test against cholangiocarcinoma cell. In our previous study [11], water extract of this plant (DM1 and DM2) exhibited promising cytotoxic activity against human breast adenocarcinoma MCF-7 $\left(\mathrm{IC}_{50}=7.7 \mu \mathrm{g} / \mathrm{ml}\right)$ but only showed moderate activity against human large cell lung carcinoma COR-L23 $\left(\mathrm{IC}_{50}=37.6 \mu \mathrm{g} / \mathrm{ml}\right)$ and human colon adenocarcinoma LS-174T $\left(\mathrm{IC}_{50}=78.4 \mu \mathrm{g} /\right.$ $\mathrm{ml})$ cell lines [16].

Investigation of comparative cytotoxic activities of the extracts of the six plants and the standard drug 5-FU against CL-6, HepG-2 Hep-2 and HRE cell lines indicate difference in responsiveness/sensitivity of different cancerous cells to these plant extracts (Table 3 and Figure 1). The results were generally in agreement with that shown in the screening test, confirming that Hep-2 was the most sensitive, while HepG2 was the most resistant cell 
Table 1 The plant species and recipes used in Thai traditional folklore which were investigated for cytotoxicity

\begin{tabular}{|c|c|c|c|c|}
\hline Family & Plant & $\begin{array}{l}\text { Part } \\
\text { used }\end{array}$ & $\begin{array}{l}\text { Voucher } \\
\text { specimen }\end{array}$ & Thai traditional Use \\
\hline Compositae & Artemisia annua $L .^{1}$ & $\mathrm{Rh}$ & SKP 051010101 & Treatment of fever, hemorrhoids [31] \\
\hline Compositae & Atractylodes lancea (thung.) DC.' & $\mathrm{Rh}$ & SKP 051011201 & Treatment of fever, colds, flu, sore throat [31] \\
\hline Cruciferae & Asclepias curassavica L. ${ }^{1,4}$ & $\mathrm{Fl}$ & SKP 057121901 & Used as analgesic [32] \\
\hline Dioscoreaceae & Dioscorea membranacea & Rh & SKP 062041305 & Treatment of cancer [16] \\
\hline Dracaenaceae & Dracaena loureiri Gagnep.' & St, Ba & SKP 065041201 & Treatment of cough, fever, inflammation [32] \\
\hline Guttiferae & Mammea siamensis Kosterm ${ }^{1}$ & $\mathrm{Fl}$ & SKP 083131901 & Restorative [31] \\
\hline Guttiferae & Mesua ferrea $L^{1}$ & $\mathrm{Fl}$ & SKP 083130601 & Treatment of dyspepsia [31] \\
\hline Myristicaceae & Myristica fragrans Houtt. ${ }^{1}$ & Sd & SKP 121130601 & Treatment of uterus pain, diarrhea [33] \\
\hline Myrtaceae & $\begin{array}{l}\text { Syzygium aromaticum (L.) Merr. \& L. } \\
\text { M. Perry' }\end{array}$ & $\mathrm{Fl}$ & SKP 123190101 & Treatment of toothache, bacterial infection [32] \\
\hline Nelumbonaceae & Nigella sativa Linn. ${ }^{1,4}$ & Sd & SKP 160141901 & Treatment of jaundice [32] \\
\hline Piperaceae & Piper chaba Linn 2,3 & $\mathrm{Fr}$ & SKP 146160301 & Used as carminative, antidiarrheal [31] \\
\hline Piperaceae & Piper interruptum Opiz. ${ }^{2,3}$ & Lf & SKP 146160901 & Treatment of choke [31] \\
\hline Piperaceae & Piper sarmentosum Roxb., ${ }^{2,3}$ & Rt & SKP 146161901 & Treatment of fever, toothache, cough, asthma [31] \\
\hline Plumbaginaceae & Plumbago indica Linn. ${ }^{2,3}$ & Rt & SKP 148160901 & Treatment of rheumatism [32] \\
\hline Smilacaceae & Smilax corbularia Kunth & Rh & SKP 179190315 & Treatment of cancer [16] \\
\hline Sapotadeae & Mimusops elengi L.' & $\mathrm{Fl}$ & SKP 171130501 & Used as cordial, tonic. Treatment of syncope [32] \\
\hline Umbelliferae & Angelica dahurica Benth. ${ }^{1}$ & Rt & SKP 199010401 & Used as antipyretic, antiasthma, anticough [33] \\
\hline Umbelliferae & Angelica sinensis (Oliv.) Diels ${ }^{1}$ & $\mathrm{Rh}$ & SKP 199010901 & Treatment of bronchitis pleurisy [33] \\
\hline Umbelliferae & Anethum graveolens $L .{ }^{1,4}$ & $\mathrm{Rt}, \mathrm{Fr}$ & SKP 199010701 & Used as carminative. Treatment of eye pain [32] \\
\hline Umbelliferae & Cuminum cyminum Linn. ${ }^{1,4}$ & $\mathrm{Sd}$ & SKP 199030301 & Treatment of dyspepsia, diarrhoea and jaundice [31] \\
\hline Umbelliferae & $\begin{array}{l}\text { Foeniculum vulgare Mill. var. dulce } \\
\text { Alef. }{ }^{1,4}\end{array}$ & $\mathrm{Sd}$ & SKP 199062201 & Used as analeptic [33] \\
\hline Umbelliferae & $\begin{array}{l}\text { Ligusticum sinense Oliv. CV. } \\
\text { Chuanxiong }\end{array}$ & Rh & SKP 199121901 & Treatment of urinary bladder channel, headache, neurodermatitis [32] \\
\hline Zingiberaceae & Amomum testaceum Ridl. ${ }^{1}$ & $\mathrm{Sd}$ & SKP 206011101 & Used as carminative, antibacterial [33] \\
\hline Zingiberaceae & Curcuma longa Linn. & Rh & SKP 206012101 & Treatment of cancer, high cholesterol, dyspepsia, gallstone [33] \\
\hline Zingiberaceae & Kaempferia galangal ${ }^{1}$ & Lf & SKP 206110701 & Antinociceptive, anti-inflammatory [33] \\
\hline Zingiberaceae & Zingiber officinale Roscoe. ${ }^{2}$ & $\mathrm{Rh}$ & SKP 206261501 & Treatment of hypercholesteremia and high level triglyceride [33] \\
\hline Zingiberaceae & Zingiber ligulatum Roxb.3 & $\mathrm{Rh}$ & SKP 206261201 & Used as anti-inflammatory [33] \\
\hline- & $\begin{array}{l}\text { Dioscorea membranacea \&Smilax } \\
\text { corbularia }\end{array}$ & - & - & Treatment of cancer [16] \\
\hline- & Ben-ja-Kul 1 Recipe & - & - & Used as restorative [31] \\
\hline- & Ben-ja-Kul 2 Recipe & - & - & Treatment of fever, cold [31] \\
\hline- & Pra-Sa-Prao-Yhai Recipe & - & - & $\begin{array}{l}\text { Used as restorative, anti-emetic, setting up proper digestive } \\
\text { system, analeptic [31] }\end{array}$ \\
\hline- & Tein-5 Recipe & - & - & Used as restorative, carminative [31] \\
\hline
\end{tabular}

Plant parts: Fr: Fruits, Fl: Flower, Lf: leaves, Rt: Root, Rh: Rhizomes, Sd: Seed, St: Stem. ${ }^{1}$ Composition in Pra-Sa-Prao-Yhai Recipe, ${ }^{2}$ Composition in Ben-ja-Kul 1 Recipe, ${ }^{3}$ Composition in Ben-ja-Kul 2 Recipe, ${ }^{4}$ Composition in Tein-5 Recipe.

line to the tested ethanolic extracts from Thai traditional folklore. All extracts possessed high activity against Hep2 cell with mean $\mathrm{IC}_{50}$ values ranging from 18.93 to 32.40 $\mu \mathrm{g} / \mathrm{ml}$. In contrast, activity against the hepatoma cell HepG2 varied markedly with mean $\mathrm{IC}_{50}$ values ranging from 9.67 to $115.47 \mu \mathrm{g} / \mathrm{ml}$. The only promising extract was from Zingiber officinal $\left(\mathrm{IC}_{50}=9.67 \pm 3.91 \mu \mathrm{g} / \mathrm{ml}\right)$. The extract from Atractylodes lancea exhibited the most potent activity against CL- 6 but the activities against the other two cancerous cells were only moderate. The extract from Zingiber officinal was most promising against HepG2 cell line, whereas that from Piper chaba was most promising against Hep-2 cell. This may suggest that HepG2 is the most resistant among the three cancerous cell lines under investigation. Only two crude extracts from Curcuma longa and Mammea siamensis showed high activity against HepG2 cell. Crude extracts from Curcuma longa exhibited high activity against both HepG2 and Hep-2 (\% survival of 13.9 and 0.6, respectively) but relatively low activity against CL- 6 cell line (\% survival of 59.9). The ethanolic extract of Mammea siamensis showed promising activity against only HepG2 cell (29.2\%) with relatively low activity against CL-6 and Hep-2 cell line with \% survival of 51.4 and 59.5, 
Table 2 Percentage survival of cancer cell lines (CL-6, HepG2, Hep-2) treated with ethanolic extract from a total of 28 plants and 5 recipes used in Thai folklore medicine at the concentration of $50 \mu \mathrm{g} / \mathrm{ml}$

\begin{tabular}{|c|c|c|c|}
\hline \multirow[t]{2}{*}{ Plant } & \multicolumn{3}{|c|}{ Cell line } \\
\hline & $\mathrm{CL}-6$ & HepG2 & Hep-2 \\
\hline Atractylodes lancea & $32.10 \pm 3.72$ & $93.80 \pm 8.09$ & $-1.38 \pm 0.67$ \\
\hline Mesua ferrea & $35.67 \pm 8.66$ & $64.62 \pm 2.92$ & $12.55 \pm 6.03$ \\
\hline Kaempferia galangal (leaf) & $36.74 \pm 11.72$ & $75.03 \pm 17.78$ & $5.65 \pm 0.08$ \\
\hline Ligusticum sinense Oliv & $43.85 \pm 6.73$ & $69.74 \pm 4.46$ & $36.81 \pm 15.56$ \\
\hline Zingiber officinal & $44.26 \pm 8.93$ & $80.65 \pm 11.92$ & $8.11 \pm 10.97$ \\
\hline Artemisia annua & $46.56 \pm 6.03$ & $95.76 \pm 11.35$ & $33.48 \pm 7.85$ \\
\hline Kaempferia galangal (flower) & $47.49 \pm 5.95$ & $69.36 \pm 16.12$ & $9.74 \pm 0.07$ \\
\hline Mimusops elengi & $48.84 \pm 0.62$ & $109.99 \pm 2.95$ & $54.44 \pm 3.24$ \\
\hline Pra-Sa-Prao-Yhai Recipe & $49.43 \pm 8.75$ & $79.55 \pm 23.90$ & $25.55 \pm 5.32$ \\
\hline Piper chaba & $50.62 \pm 3.10$ & $72.25 \pm 1.15$ & $12.42 \pm 7.99$ \\
\hline Mammea siamensis & $51.35 \pm 3.89$ & $29.17 \pm 12.28$ & $59.52 \pm 44.80$ \\
\hline Angelica sinensis & $51.77 \pm 7.53$ & $81.94 \pm 12.48$ & $33.77 \pm 9.19$ \\
\hline Syzygium aromaticum & $55.40 \pm 0.51$ & $72.51 \pm 15.32$ & $34.30 \pm 21.33$ \\
\hline Nigella sativa & $58.02 \pm 2.25$ & $118.49 \pm 6.33$ & $43.68 \pm 0.49$ \\
\hline Curcuma longa & $59.86 \pm 6.49$ & $13.87 \pm 12.88$ & $0.57 \pm 0.80$ \\
\hline Ben-ja-Kul 1 Recipe & $61.33 \pm 2.84$ & $87.19 \pm 6.98$ & $33.12 \pm 9.68$ \\
\hline Foeniculum vulgare & $61.62 \pm 8.86$ & $83.26 \pm 4.78$ & $50.55 \pm 11.04$ \\
\hline Anethum graveolens & $63.28 \pm 12.92$ & $97.47 \pm 7.40$ & $55.11 \pm 4.37$ \\
\hline Ben-ja-Kul 2 Recipe & $63.78 \pm 5.15$ & $93.02 \pm 9.15$ & $46.27 \pm 4.00$ \\
\hline Piper pendulispicum & $64.94 \pm 5.78$ & $62.66 \pm 16.28$ & $25.60 \pm 14.67$ \\
\hline Myristica fragrans & $66.11 \pm 2.11$ & $89.14 \pm 20.97$ & $33.00 \pm 13.32$ \\
\hline Piper sarmentosum & $69.20 \pm 4.39$ & $81.95 \pm 10.79$ & $34.09 \pm 8.96$ \\
\hline Amomum testaceum & $72.30 \pm 11.24$ & $90.74 \pm 12.47$ & $71.24 \pm 2.10$ \\
\hline Cuminum cyminum & $74.07 \pm 6.38$ & $87.25 \pm 19.06$ & $39.28 \pm 7.50$ \\
\hline Zingiber ligulatum & $74.68 \pm 2.17$ & $106.55 \pm 14.23$ & $44.14 \pm 2.28$ \\
\hline Dioscorea membranacea & $76.05 \pm 2.57$ & $90.86 \pm 16.65$ & $59.90 \pm 29.93$ \\
\hline Plumbago indica & $77.79 \pm 14.31$ & $61.83 \pm 20.45$ & $40.50 \pm 13.52$ \\
\hline Tein-5 Recipe & $79.73 \pm 2.56$ & $89.61 \pm 16.60$ & $63.21 \pm 3.74$ \\
\hline Dracaena loureiri & $81.29 \pm 10.42$ & $96.18 \pm 5.81$ & $20.97 \pm 28.05$ \\
\hline Asclepias curassavica & $81.63 \pm 3.99$ & $87.47 \pm 13.67$ & $47.45 \pm 5.01$ \\
\hline Smilax corbularia & $81.77 \pm 9.61$ & $147.02 \pm 18.39$ & $68.96 \pm 13.38$ \\
\hline Dioscorea membranacea \&Smilax corbularia & $82.31 \pm 0.39$ & $141.96 \pm 14.64$ & $76.64 \pm 13.42$ \\
\hline Angelica dahurica & $85.16 \pm 5.55$ & $80.18 \pm 13.41$ & $48.68 \pm 2.68$ \\
\hline
\end{tabular}

Data are presented as mean \pm SD from 3 independent experiments, triplicate for each).

Table 3 Cytotoxicity of 5-FU and ethanolic extracts from 5 medicinal plants and one recipe with promising activity

\begin{tabular}{|c|c|c|c|c|c|c|c|}
\hline \multirow[t]{3}{*}{ Plants } & \multicolumn{7}{|c|}{ Cell line } \\
\hline & \multicolumn{2}{|l|}{$\mathrm{CL}-6$} & \multicolumn{2}{|c|}{ HepG2 } & \multicolumn{2}{|l|}{ Hep-2 } & \multirow{2}{*}{$\begin{array}{l}\text { HRE } \\
I_{50}\end{array}$} \\
\hline & $\mathrm{I} \mathrm{C}_{50}$ & SI & $I C_{50}$ & SI & $I C_{50}$ & SI & \\
\hline Atractylodes lancea & $24.09 \pm 3.40$ & 8.6 & $76.68 \pm 15.94$ & 2.7 & $29.35 \pm 8.66$ & 7.1 & $207.59 \pm 7.97$ \\
\hline Kaempferia galangal (leaf) & $37.36 \pm 3.98$ & 2.9 & $115.47 \pm 26.23$ & 0.9 & $18.99 \pm 10.33$ & 5.7 & $119.20 \pm 14.91$ \\
\hline Zingiber officinal & $34.26 \pm 7.65$ & 3.5 & $9.67 \pm 3.91$ & 12.6 & $32.40 \pm 6.70$ & 3.8 & $121.50 \pm 5.20$ \\
\hline Piper chaba & $40.74 \pm 5.30$ & 4.5 & $68.09 \pm 22.58$ & 2.7 & $18.93 \pm 5.03$ & 9.8 & $119.14 \pm 9.94$ \\
\hline Pra-Sa-Prao-Yhai recipe & $44.12 \pm 11.58$ & 5.9 & $125.07 \pm 3.08$ & 2.11 & $20.99 \pm 2.68$ & 12.5 & $263.51 \pm 29.06$ \\
\hline Mesua ferrea & $48.23 \pm 5.84$ & 2.5 & $86.47 \pm 4.38$ & 1.4 & $19.22 \pm 5.31$ & 6.3 & $121.77 \pm 29.08$ \\
\hline 5-FU $(\mu \mathrm{M})$ & $757.00 \pm 77.16$ & 2.0 & $633.08 \pm 284.25$ & 2.4 & $141.49 \pm 17.14$ & 10.8 & $1542.20 \pm 1529.1$ \\
\hline
\end{tabular}

Data are presented otherwise specified as mean $\pm S D$ of $\mathrm{IC}_{50}(\mu \mathrm{g} / \mathrm{ml})$ from 3 independent experiments, triplicate for each. 


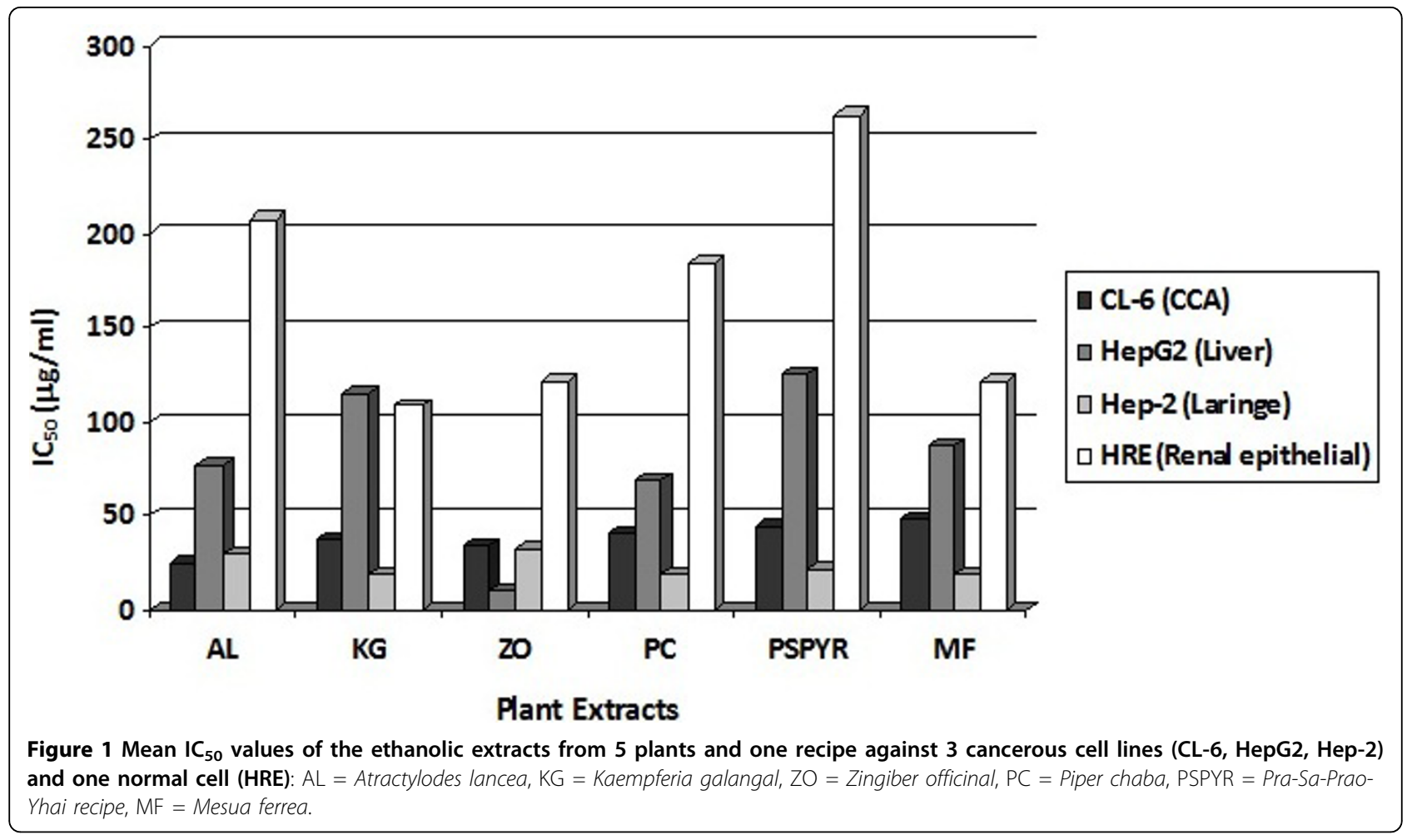

respectively (Table 2). Selectivity of the cytotoxic activity of the six tested extracts was determined by comparing the cytotoxic activity $\left(\mathrm{IC}_{50}\right)$ of each plant extract against each cancerous cell with that of the normal human cell HRE (Table 3). Results were expressed as selectivity index (SI). SI of greater than 3 was considered as highly selective. The extract from Atractylodes lancea appears to be both the most potent and most selective against cholangiocarcinoma $\left(\mathrm{IC}_{50}=24.09 \pm 3.40 \mu \mathrm{g} / \mathrm{ml}\right.$, SI 8.6), whereas that from Zingiber officinal appears to be the most potent and most selective against HepG2 $\left(\mathrm{IC}_{50}=\right.$ $9.67 \pm 3.91 \mu \mathrm{g} / \mathrm{ml}, \mathrm{SI}=12.6)$. For Hep-2 cell, Piper chaba $\left(\mathrm{IC}_{50}=18.63 \pm 5.03 \mu \mathrm{g} / \mathrm{ml}, \mathrm{SI}=9.8\right)$ and Pra-Sa-PraoYhai recipe $\left(\mathrm{IC}_{50}=20.99 \pm 2.68 \mu \mathrm{g} / \mathrm{ml}\right.$, SI $\left.=12.5\right)$ exhibited the most promising and most selective cytotoxic activity.

Difference in responsiveness/sensitivity of different cancerous cells to different chemotherapeutics are commonly observed in various studies $[11,12,17,18]$. The responsiveness of all the four cells to 5 -FU varied according to cell types, particularly with CL-6 cell $\left(\mathrm{IC}_{50}=757 \pm\right.$ $72.16 \mu \mathrm{M})$. Although 5 -FU is the standard chemotherapeutic drug used in the treatment of human cholangiocarcinoma, evidence of 5-FU resistance has been reported both in vitro [9] and in vivo [7]. It has been demonstrated in a previous study [19] that variations in the sensitivity to chemotherapeutic drugs were observed among the five intrahepatic cholangiocarcinoma cell lines and sensitivity to chemotherapeutic drug. Cholangiocarcinoma is a fatal disease which is highly resistant to anticancer drugs. It is noted that the $\mathrm{IC}_{50}$ values of 5 -FU observed in the present study and the previous study [19] were much higher than those reported in other cancerous cell lines, e.g., colon carcinoma (HCC-48, COLO20) [20] and cervical squamous carcinoma ( $\mathrm{SiHa}, \mathrm{HeLa}$ ) cell lines [21]. This suggests low sensitivity of cholangiocarcinoma to all chemotherapeutics including those obtained from medicinal plant source, which is probably due in part to enhanced resistance to apoptosis. Several genes involved in the apoptosis, detoxification and efflux processes have been reported to influence resistance to chemotherapeutic agents, for examples multidrug resistance protein (MDR1) and multidrug-resistance associated proteins (MRPs) [22], glutathione-S-transferase (GST) [23], dihydropyrimidine dehydrogenase (DPD) [24], and galectin-3 [25]. Active compound from Atractylodes lancea has been shown to exhibit strong inhibitory effects on 5lipoxygenase (5-LOX) and cyclooxygenase-1 (COX-1), but exhibited only weak antioxidative activities $\left[\mathrm{IC}_{50}=\right.$ $0.1 \mu \mathrm{M}$ (5-LOX), $2 \mu \mathrm{M}$ (COX-1), $9 \mu \mathrm{M}$ (PMN/FMLP), 28 $\mu \mathrm{M}$ (PMN/OZ)] [26]. The alcoholic extracts of Kaempferia galangal showed high cytotoxicity against SW 620 with $\mathrm{IC}_{50}$ less than $30 \mu \mathrm{g} / \mathrm{ml}$ and showed moderate cytotoxicity against cancer cells DU145 (human prostate cancer cell line), PA1 (human ovarian teratocarcinoma cell line), and B16F10 (murine melanoma cells) and were not 
selective against cancer cells when compared to Vero cells [27]. In the case of Zingiber officinal methanolic extracts, cytotoxic activities against human A549 (adenocarcinomic alveolar basal epithelial cell line), SK-OV-3 (ovarian carcinoma cell line), SK-MEL-2 (skin Melanoma cell line), and HCT15 (colon carcinoma cell line) have been reported [28]. From the study of Sakpakdeejaroen et al., piperine, the active compound of Piper chaba, showed cytotoxic activity against MCF-7 (breast cancer cell line) with $\mathrm{IC}_{50}$ equal to $35.72 \mu \mathrm{M}$ [29]. The active compounds of Mesua ferrea including phenylcoumarins, xanthones and triterpenoids were reported to possess cytotoxic and antibacterial activities [30].

\section{Conclusions}

Results obtained from this study indicate that 6 out of a total of 28 plants and 5 recipes (Atractylodes lancea, Kaempferia galangal, Zingiber officinal, Piper chaba, Mesua ferrea, and Pra-Sa-Prao-Yhai recipe) used in Thai folklore medicine exhibited promising cytotoxic activity against CL-6 human cholangiocarcinoma cell line. Sensitivity to other cancerous cell lines varied according to cell types and the hepatocarcinoma HepG2 appears to be the most resistant cell line to the tested extracts. The extract from Atractylodes lancea appears to be both the most potent and most selective against cholangiocarcinoma, whereas that from Zingiber officinal appears to be the most potent and most selective against HepG2. The extract from Piper chaba $\left(\mathrm{IC}_{50}=18.63 \mu \mathrm{g} / \mathrm{ml}\right.$, SI = 9.8) and Pra-Sa-Prao-Yhai recipe $\left(\mathrm{IC}_{50}=20.99 \mu \mathrm{g} / \mathrm{ml}\right.$, SI $=12.5$.) exhibited the most promising and most selective cytotoxic activity against Hep-2 cell line. Further investigation of all the six extracts for their cytotoxic activity against cholangiocarcinoma in hamster model is underway to fully assess the anticancer activity in vivo.

\section{Acknowledgements}

The study was supported by The Commission on Higher Education, Ministry of Education, Thailand.

\section{Author details}

${ }^{1}$ Graduate Program in Biomedical Sciences, Thammasat University (Rangsit Campus), Pathumtani 12121, Thailand. ${ }^{2}$ Applied Thai Traditional Medicine Center, Thammasart University (Rangsit Campus), Pathumtani 12121, Thailand.

\section{Authors' contributions}

KN conceived and designed the study, reviewed and finalized the manuscript. WM performed the laboratory work, and drafted the manuscript. W obtained the financial support for the project, reviewed and provided comments and suggestions to improve the quality of the manuscript. WC performed data analysis. Al prepared the medicinal plants and all the herbal extracts. All authors read and approved the final manuscript.

\section{Competing interests}

The authors declare that they have no competing interests.

Received: 7 May 2010 Accepted: 28 September 2010 Published: 28 September 2010
References

1. Khuhaprema T, Srivatanakul P: Liver and Bile Duct. In Cancer in Thailand Vol. IV, 1998-2000. Edited by: Khuhaprema T, Srivatanakul P, Wiangnon S, Sumitsawan Y, Attasara P. Bangkok Medical Publisher; 2007:36-38.

2. Nakanuma Y, Harada K, Ishikawa A, Zen Y, Sasaki M: Anatomic and molecular pathology of intrahepatic cholangiocarcinoma. J Hepatobiliary Pancreat Surg 2003, 10:265-81.

3. Watanapa $P$, Watanapa WB: Liver fluke-associated cholangiocarcinoma. $\mathrm{Br}$ J Surg 2002, 89:962-970.

4. Prabhleen C, Todd HB: Cholangiocarcinoma. Curr Treat Opt Gastroenterol 2005, 8:493-502.

5. Sirica AE: Cholangiocarcinoma: molecular targeting strategies for chemoprevention and therapy. Hepatology 2005, 41:5-15.

6. Thongprasert S: The role of chemotherapy in cholangiocarcinoma. Ann Oncol 2005, 16:93-96.

7. Patt $Y Z$, Hassan MM, Lozano RD, Waugh KA, Hoque AM, Frome Al, Lahoti $\mathrm{S}$, Ellis L, Vauthey JN, Curley SA, Schnirer II, Raijman I: Phase II trial of cisplatin, interferon alpha-2b, doxorubicin, and 5-fluorouracil for biliary tract cancer. Clin Canc Res 2001, 7:3375-80.

8. Lee MA, Woo IS, Kang JH, Hong YS, Lee KS: Epirubicin, cisplatin, and protracted infusion of 5-FU (ECF) in advanced intrahepatic cholangiocarcinoma. J Cancer Res Clin Oncol 2004, 130:346-50.

9. Namwat N, Amimanan P, Loilome W, Jearanaikoon P, Sripa B, Bhudhisawasdi V, Tassaneeyakul W: Characterization of 5-FluorouracilResistant Cholangio-carcinoma Cell Lines. Chemotherapy 2008, 54:343-351.

10. Subchareon P: Handbook of Anticancer: Thai Traditional Medicine: New Concept for Treated Cancer. Thai Traditional Medicine Institute, Bangkok 1998, 3.

11. Itharat A, Houghton Peter J, Eno-Amooquaye E, Burke PJ, Sampson Julia H, Raman Amala: In vitro cytotoxic activity of Thai medicinal plants used traditionally to treat cancer. J Ethnopharmacol 2004, 90:33-38.

12. Prayong $P$, Barusrux S, Weerapreeyakul N: Cytotoxic activity screening of some indigenous Thai plants. Fitoterapia 2008, 79:598-601

13. Mosmann T: Rapid colorimetric assay for cellular growth and survival: application to proliferation and cytotoxicity assays. J Immunol Methods 1983, 65:55-63.

14. Saetung A, Itharat A, Dechsukum C, Wattanapiromsakul C, Keawpradub N, Ratanasuwan P: Cytotoxicity activity of Thai medicinal plants. Songklanakarin J Sci Technol 2005, 27:469-478.

15. Boik J: Natural Compounds in Cancer Therapy. Oregon Medical Press, Minnesota, USA 2001.

16. Itharat $A$, Supavita $T$, Singchangchai $P$, Kajjarun $U$, Ratanasuwan $P$, Pongpeerachote S, Chantaptawan V: Identification and Specification of Khao-Yen-Neua and Khao-Yen-Tai from Traditional Doctors in Thailand. Prince of Songkla University, Songkla 1999, 9.

17. Fouche G, Cragg GM, Pillay P, Kolesnikova N, Maharaj VJ, Senabe J: In vitro anticancer screening of South African plants. J Ethnopharmacol 2008, 119:455-461.

18. Ramzi AM, Ulrike L, Renate $G$, Bednarski JPatrick: Studies of the in vitro anticancer, antimicrobial and antioxidant potentials of selected Yemeni medicinal plants from the island Soqotra. BMC Compl Alt Med 2009, 9:7.

19. Tepsiri N, Chaturat L, Sripa B, Namwat W, Wongkham S, Bhudhisawasdi V, Tassaneeyakul W: Drug sensitivity and drug resistance profiles of human intrahepatic cholangiocarcinoma cell lines. World J Gastroenterol 2005, 11:2748-2753.

20. Nishiyama M, Yamamoto W, Park JS, Okamoto R, Hanaoka H, Takano H, Saito N, Matsukawa M, Shirasaka T, Kurihara M: Low-dose cisplatin and 5fluorouracil in combination can repress increased gene expression of cellular resistance determinants to themselves. Clin Cancer Res 1999, 5:2620-2628

21. Laochariyakul $P$, Ponglikitmongkol M, Mankhetkorn S: Functional study of intracellular P-gp- and MRP1-mediated pumping of free cytosolic pirarubicin into acidic organelles in intrinsic resistant SiHa cells. Can J Physiol Pharmacol 2003, 81:790-799.

22. Gottesman MM, Fojo T, Bates SE: Multidrug resistance in cancer: role of ATP-dependent transporters. Nat Rev Cancer 2002, 2:48-58.

23. Tew KD: Glutathione-associated enzymes in anticancer drug resistance. Cancer Res 1994, 54:4313-4320.

24. Nita ME, Tominaga O, Nagawa H, Tsuruo T, Muto T: Dihydropyrimidine dehydrogenase but not thymidylate synthase expression is associated 
with resistance to 5 -fluorouracil in colorectal cancer.

Hepatogastroenterology 1998, 45:2117-2122.

25. Wongkham S, Junking M, Wongkham C, Sripa B, Chur-In S, Araki N:

Suppression of galectin-3 expression enhances apoptosis and

chemosensitivity in liver fluke-associated cholangiocarcinoma. Cancer Sci 2009, 100:2077-84.

26. Resch M, Heilmann J, Steigel A, Bauer R: Further phenols and polyacetylenes from the rhizomes of Atractylodes lancea and their antiInflammatory activity. Planta Med 2001, 67:437-442.

27. Jagadish P, Raghu CH, Vinod KS, Latha KP: Potent selective cytotoxic activity of Kaempferia galangal $L$. rhizome against cancer cell cultures. Int J Pharm Bio Sci 2010, 1(2)

28. Ju SK, Sa IL, Hye WP, Jae HY, Tae YS, Youn CK, Nam IB, Sung HK, Sang UC, Byoung MK, Kang HL, Mun YJ, Dae KK: Cytotoxic Components from the Dried Rhizomes of Zingiber officinale Roscoe. Arch Pharm Res 2008, 31:415-418.

29. Sakpakdeejaroen I, Itharat A: Cytotoxic compounds against breast Adenocarcinoma cells (mcf-7) from pikutbenjakul. J Health Res 2009, 23:71-76.

30. Verotta L, Lovaglio E, Vidari G, Finzi PV, Neri MG, Raimondi A, Parapini $S$, Taramelli D, Riva A, Bombardelli E: 4-Alkyl- and 4-phenylcoumarins from Mesua ferrea as promising multidrug resistant antibacterials. Phytochemistry 2004, 65:2867.

31. Chayamarit K: Thai Medicinal Plants. Department of Forestry, Bangkok, 5 1995.

32. Phuphathanaphong L: Thai Medicinal Plants. Department of Forestry, Bangkok, 21979.

33. Phuphathanaphong L: Thai Medicinal Plants. Department of Forestry, Bangkok, 31982

\section{Pre-publication history}

The pre-publication history for this paper can be accessed here: http://www.biomedcentral.com/1472-6882/10/55/prepub

doi:10.1186/1472-6882-10-55

Cite this article as: Mahavorasirikul et al:: Cytotoxic activity of Thai medicinal plants against human cholangiocarcinoma, laryngeal and hepatocarcinoma cells in vitro. BMC Complementary and Alternative Medicine 2010 10:55.

\section{Submit your next manuscript to BioMed Central and take full advantage of:}

- Convenient online submission

- Thorough peer review

- No space constraints or color figure charges

- Immediate publication on acceptance

- Inclusion in PubMed, CAS, Scopus and Google Scholar

- Research which is freely available for redistribution 